\title{
PENGARUH PENAMBAHAN TEPUNG DURI IKAN LELE DUMBO (CLARIAS GARIEPINUS) DAN BUBUR RUMPUT LAUT (EUCHEUMA COTTONII) TERHADAP KADAR KALSIUM, KADAR SERAT KASAR DAN KESUKAAN KERUPUK
}

\author{
Mega Ariyani, Fitriyono Ayustaningwarno*) \\ Program Studi Ilmu Gizi Fakultas Kedokteran Universitas Diponegoro \\ Jl.Dr.Sutomo No.14, Semarang, Telp (024) 8453708, Email : gizifk@undip.ac.id
}

\begin{abstract}
Background : Indonesia society were lack of calcium daily intake, i.e. an average of $254 \mathrm{mg} /$ day. Milk and supplements were calcium sources which have been widely known but could not reached by society. In addition, Indonesia society were lack of fiber daily intake, i.e. an average of $10.5 \mathrm{~g} /$ day. Calcium and fiber levels enrichment could be done by utilizing local foods such as catfish bone, which catfish were found in the markets, it's price was affordable, and levels of calcium catfish bone crackers were more than shrimp and meat fish crackers's, and Eucheuma cottonii seaweed, was one with a high fiber sources, and did not contain fitat acids which could inhibit the absorption of calcium, on crackers, as a product that easily accepted, easy to reached by many quarters of the economy, and covered all ages.

Objective: analyzed effect the addition of catfish bone flour and seaweed porridge variations against the levels of calcium, crude fiber, and preference include color, odor, flavor, and texture of crackers.

Method : it was one factor completely randomized experimental study which used 6 addition level of catfish bone flour and seaweed porridge which were 25\%:0\%, 20\%:5\%, 15\%:10\%, 10\%:15\%, 5\%:20\%, 0\%:25\%, dan 0\%:0\%. Statistic analysis of calcium and crude fiber levels used One Way ANOVA CI 95\% then Tukey and LSD as posthoc test. Statistic analysis of preference used Friedman CI 95 \% then Wilcoxon sign rank test as posthoc test.

Results : Catfish bone flour and seaweed porridge variation on crackers effected on increasing calcium and crude fiber levels and preference, include color, odor, flavor and texture. The highest calcium levels found on crackers with the addition of catfish bone flour $25 \%$, and the highest crude fibers levels found on crackers with the addition of seaweed porridge $25 \%$.

Conclusion : Addition of catfish bone flour could increase calcium levels. Addition of seaweed porridge could increase crude fiber levels and preference include color, odor, flavor and texture.
\end{abstract}

Kata kunci : less of calcium and fiber intake; levels of clcium and crude fiber; crackers; Catfish bone flour and seaweed porridge

\section{ABSTRAK}

Latar Belakang : Masyarakat Indonesia kurang mencukupi asupan kalsiumnya sehari-hari, yakni rata-rata sebesar $254 \mathrm{mg} /$ hari. Susu dan suplemen merupakan sumber kalsium yang telah banyak diketahui tetapi tidak dapat dijangkau oleh masyarakat. Selain itu, masyarakat Indonesia kurang mencukupi asupan serat sehari-hari, yakni rata-rata sebesar 10,5 g/hari. Pengkayaan kadar kalsium dan serat dapat dilakukan dengan pemanfaatan bahan lokal seperti duri ikan lele dumbo, dimana ikan lele dumbo banyak dijumpai di pasar, harganya terjangkau, dan kadar kalsium kerupuk duri ikan lele dumbo lebih banyak dibandingkan kerupuk udang dan daging ikan, dan Eucheuma cottonii, merupakan salah satu rumput laut dengan sumber serat yang cukup tinggi, dan tidak mengandung asam fitat yang dapat menghambat absorbsi kalsium, pada kerupuk sebagai produk yang mudah diterima, mudah dijangkau berbagai kalangan ekonomi, dan mencakup segala usia.

Tujuan : menganalisis pengaruh variasi penambahan tepung duri ikan lele dumbo dan rumput laut terhadap kadar kalsium, serat kasar, dan kesukaan yang meliputi warna, aroma, rasa, dan tekstur kerupuk.

Metode : merupakan penelitian eksperimental acak lengkap satu faktor dengan 6 taraf perlakuan dan kontrol. Variasi perlakuan tepung duri ikan lele dumbo dan bubur rumput laut adalah 25\%:0\%, 20\%:5\%, 15\%:10\%, 10\%:15\%, 5\%:20\%, 0\%:25\%, dan 0\%:0\%. Analisis statistik kadar kalsium dan serat kasar menggunakan uji One Way ANOVA CI 95\% dilanjutkan Posthoc test Tukey dan LSD. Analisis statistik kesukaan menggunakan uji Friedman CI 95\% dilanjutkan uji Wilcoxon sign rank test.

Hasil : variasi penambahan tepung duri ikan lele dumbo dan bubur rumput laut pada kerupuk berpengaruh terhadap peningkatan kadar kalsium dan serat kasar juga kesukaan meliputi warna, aroma, rasa, dan tekstur. Kadar kalsium tertinggi terdapat pada kerupuk dengan penambahan tepung duri ikan lele dumbo 25\%, dan kadar serat kasar tertinggi terdapat pada kerupuk dengan penambahan bubur rumput laut $25 \%$.

Kesimpulan : semakin tinggi penambahan tepung duri, semakin tinggi kadar kalsium kerupuk. Semakin tinggi penambahan bubur rumput laut, semakin tinggi kadar serat kasar dan kesukaan terhadap kerupuk.

${ }^{*}$ Penulis Penanggungjawab 
Kata kunci : Kekurangan asupan kalsium dan serat; kadar kalsium dan serat kasar; kerupuk; tepung duri ikan lele dumbo dan bubur rumput laut

\section{PENDAHULUAN}

Masyarakat Indonesia mengonsumsi kalsium rata-rata hanya sebesar $254 \mathrm{mg}$ per hari ${ }^{1}$ padahal kebutuhan kalsium yang dianjurkan menurut Widyakarya Pangan dan Gizi LIPI (1998) adalah $500-800 \mathrm{mg}$ per hari. $^{2}$ Hal ini menunjukkan bahwa konsumsi kalsium masyarakat Indonesia hanya sepertiga dari kebutuhan kalsium yang dianjurkan. ${ }^{1}$ Konsumsi kalsium yang kurang dapat menyebabkan kerusakan gigi, gangguan pertumbuhan tulang, darah sukar membeku, dan kekejangan otot ${ }^{2}$ sehingga asupan sumber kalsium yang cukup diperlukan untuk menghindari akibat kekurangan konsumsi kalsium tersebut.

Susu dan suplemen merupakan sumber kalsium yang telah banyak diketahui, tetapi tidak dapat dijangkau oleh seluruh masyarakat. ${ }^{3}$ Tahu, tempe, dan sayuran hijau merupakan sumber kalsium yang dapat dijangkau ${ }^{4}$, tetapi mengandung asam fitat dan asam oksalat yang dapat menghambat absorbsi kalsium. ${ }^{2}$ Selain itu, semua jenis ikan dapat menjadi sumber kalsium yang baik, meskipun tidak semua jenis ikan dapat dijangkau oleh seluruh masyarakat. Namun, kandungan kalsium pada ikan tidak hanya pada dagingnya, tetapi juga pada durinya. ${ }^{4}$

Duri ikan merupakan salah satu limbah yang belum dimanfaatkan dengan baik padahal duri ikan mengandung kalsium yang tinggi. ${ }^{5}$ Duri ikan yang dapat dimanfaatkan salah satunya adalah duri ikan lele dumbo. Duri ikan lele dumbo yang dihasilkan semakin meningkat seiring dengan perkembangan produksi ikan lele dumbo (Clarias gariepinus) yang mencapai 273.554 ton pada tahun $2010 .^{6}$ Sementara itu, ikan lele dumbo memiliki harga yang terjangkau ${ }^{7}$. Selain itu, kandungan kalsium duri ikan lele dumbo yang telah diolah menjadi kerupuk lebih tinggi dibandingkan kerupuk udang dan daging ikan. ${ }^{8,9}$

Selain kekurangan konsumsi kalsium, masyarakat Indonesia pun kekurangan konsumsi serat. Masyarakat Indonesia mengonsumsi serat rata-rata hanya $10,5 \mathrm{~g}$ per hari ${ }^{10}$ sementara kebutuhan serat yang dianjurkan menurut Lembaga Kanker Amerika adalah $20-30$ g per hari. ${ }^{2}$ Konsumsi serat yang kurang dapat menyebabkan kegemukan, konstipasi, hemoroid, diabetes mellitus, jantung koroner, apendikitis, divertikulosis dan kanker kolon sehingga diperlukan asupan sumber serat yang cukup. ${ }^{2}$
Salah satu sumber serat yang cukup tinggi adalah rumput laut. ${ }^{11}$ Produksi rumput laut di Indonesia mencapai 3,082 juta ton pada tahun $2010 .{ }^{12}$ Salah satu jenis rumput laut yang dapat dimanfaatkan adalah Eucheuma cottonii. Rumput laut jenis ini digunakan dalam pembuatan berbagai macam produk makanan dan minuman karena memiliki sifat yang tidak mengurangi kelezatan makanan. $^{13}$ Selain itu, rumput laut tidak mengandung asam fitat yang dapat menghambat absorbsi kalsium. ${ }^{14}$

Pengkayaan kalsium dan serat dapat dilakukan dengan memanfaatkan kedua bahan pangan tersebut, yaitu duri ikan lele dumbo dan rumput laut menjadi salah satu bentuk pangan yang mudah diterima oleh masyarakat. Salah satu bentuk pangan tersebut adalah kerupuk karena mudah dijangkau oleh berbagai kalangan ekonomi, dan dikonsumsi oleh segala usia ${ }^{15}$ sehingga diharapkan dapat menjadi snack yang kaya kalsium dan serat. Tujuan umum penelitian ini adalah menganalisis pengaruh penambahan tepung duri ikan lele dumbo dan bubur rumput laut terhadap kadar kalsium, dan serat kasar serta kesukaan kerupuk.

\section{METODE}

Penelitian yang dilakukan termasuk dalam bidang ilmu Food Production. Penelitian ini dilaksanakan mulai bulan Agustus hingga September 2012 di Laboratorium Teknologi Pangan dan Laboratorium Kimia Fakultas Ilmu Kesehatan Universitas Muhammadiyah Semarang.

Penelitian ini merupakan penelitian eksperimental dengan rancangan acak lengkap satu faktor dengan tujuh perlakuan termasuk kontrol yang dilakukan sebanyak tiga kali pengulangan. Selanjutnya, dilakukan pengujian kadar kalsium dan serat kasar secara duplo serta pengujian kesukaan kerupuk. Penelitian ini dilakukan dengan tiga tahap yaitu penepungan duri ikan lele dumbo dan pembuburan rumput laut, pembuatan kerupuk, dan analisis data kadar kalsium, serat kasar serta kesukaan kerupuk.

Ikan lele dumbo yang digunakan berasal dari Boyolali dan berusia 3 bulan dengan berat antara 0,1-1,5 kg/ekor. Ikan lele tersebut dikukus dan diambil dagingnya untuk diolah, sedangkan durinya digunakan dalam penelitian ini dan diolah menjadi tepung duri. Proses pembuatan tepung 
duri dilakukan dalam beberapa tahap. Pertama, duri yang berasal dari ikan lele yang telah dikukus dan diambil dagingnya dibersihkan dari daging yang masih menempel, direbus selama 4 jam lalu dibersihkan. Kemudian, duri tersebut direbus selama 4 jam dan dibersihkan kembali. Kedua, duri tersebut dimasukkan ke dalam autoclave dengan tekanan $1,5 \mathrm{~atm}$ dan suhu $121^{\circ} \mathrm{C}$ selama 1 jam. ${ }^{16}$ Ketiga, duri tersebut dikeringkan selama 48 jam di dalam lemari pengering dengan suhu $60^{\circ} \mathrm{C}$. Terakhir, duri tersebut digiling dengan mesin penggiling dan diayak menggunakan ayakan dengan mesh size $100 \mu \mathrm{m}$.

Rumput laut yang digunakan berasal dari perairan Jepara dan berusia 45 hari. Pada penelitian ini, rumput laut tersebut dihaluskan menjadi bubur rumput laut. Proses pembuatan bubur rumput laut dilakukan dengan beberapa tahap. Pertama, Eucheuma cottonii kering direndam dalam air bersih $^{17}$ selama 2 hari dengan penggantian air setiap hari. Kedua, rumput laut tersebut dibersihkan dari kotoran yang menempel. Terakhir, rumput laut tersebut diblender hingga halus. ${ }^{17}$
Tepung duri ikan lele dumbo dan bubur rumput laut tersebut dijadikan sebagai bahan tambahan pembuatan kerupuk. Persentase penambahan tepung duri yang dilakukan berdasarkan penelitian yang telah dilakukan oleh Rikah, yang menyatakan bahwa adonan kerupuk dengan penambahan tepung duri hingga 30\% dapat diterima oleh panelis, sedangkan kerupuk dengan penambahan tepung duri di atas 30\% membuat adonan kerupuk tidak dapat mengeras pada saat didinginkan sehingga adonan tidak dapat diiris dan tidak dapat mengembang saat digoreng. ${ }^{5}$ Persentase penambahan bubur rumput laut yang dilakukan berdasarkan penelitian yang telah dilakukan oleh Diah, yang menyatakan bahwa kerupuk dengan penambahan rumput laut hingga $40 \%$ memiliki pengembangan yang baik, sedangkan kerupuk dengan penambahan di atas $40 \%$ memiliki pengembangan yang kurang baik. ${ }^{18}$ Persentase penambahan tepung duri ikan lele dumbo dan bubur rumput laut pada kerupuk yang dibuat disajikan pada Tabel 1.

Tabel 1. Perlakuan Kerupuk dengan Penambahan Tepung Duri Ikan Lele Dumbo dan Bubur Rumput Laut

\begin{tabular}{lccccccc}
\hline \multirow{2}{*}{ Bahan } & $\mathrm{K}$ & $\mathrm{F} 1$ & $\mathrm{~F} 2$ & $\mathrm{~F} 3$ & $\mathrm{~F} 4$ & $\mathrm{~F} 5$ & F6 \\
\cline { 2 - 8 } & $0 \%$ & 25 & $20 \%$ & $15 \%$ & $10 \%$ & $5 \%$ & $0 \%$ \\
\hline $\begin{array}{l}\text { Tepung duri ikan lele } \\
\text { dumbo }\end{array}$ & $0 \%$ & $0 \%$ & $5 \%$ & $10 \%$ & $15 \%$ & $20 \%$ & $25 \%$ \\
Bubur rumput laut & 0 &
\end{tabular}

Kerupuk dibuat dengan cara sebagian tepung tapioka, garam, soda kue, dan bawang putih dicampur dengan sedikit air lalu dimasak dan diaduk hingga membentuk bubur. Adonan tersebut dibiarkan dingin terlebih dahulu setelah itu telur ditambahkan ke dalam adonan dan diaduk hingga homogen. Bubur rumput laut dimasukkan ke dalam adonan tersebut dan diaduk hingga homogen. Kemudian tepung duri ikan lele dumbo dimasukkan ke dalam adonan tersebut dan diaduk hingga homogen. Sisa tepung tapioka dimasukkan sedikit demi sedikit hingga adonan tersebut kalis. Selanjutnya, adonan tersebut dibentuk silinder dengan diameter $3 \mathrm{~cm}$. Adonan tersebut dibungkus dengan daun pisang, dikukus selama 1,5 jam lalu, didinginkan semalam, dipotong dengan ketebalan 1-2 $\mathrm{mm}$, dan dijemur hingga kering di dalam lemari pengering. Kerupuk yang telah kering ditandai dengan kerupuk mudah dipatahkan. Kerupuk digoreng dengan menggunakan minyak goreng dengan jenis yang sama selama 10 detik dengan suhu $180-200^{\circ} \mathrm{C}$.
Data yang dikumpulkan adalah data dari variabel terikat yaitu kadar kalsium dan serat kasar serta kesukaan kerupuk dengan penambahan tepung duri ikan lele dumbo dan bubur rumput laut. Kadar kalsium menggunakan metode permanganometri ${ }^{19}$, kadar serat kasar menggunakan metode gravimetri, ${ }^{20}$ sedangkan kesukaan pada kerupuk yang telah digoreng menggunakan uji hedonik dengan lima skala, yaitu $1=$ tidak suka, $2=$ agak tidak suka, $3=$ netral, $4=$ =agak suka, dan 5=suka. ${ }^{21}$ Penilaian tersebut meliputi rasa, warna, aroma, dan tekstur. Penilaian kesukaan setiap pengulangan dilakukan oleh 30 orang panelis agak terlatih, yaitu mahasiswa Program Studi Ilmu Gizi Fakultas Kedokteran Universitas Diponegoro.

Data yang telah terkumpul tersebut dianalisis menggunakan program komputer. Data kadar kalsium dan serat kasar dianalisis dengan uji One-way Anova yang dilanjutkan dengan uji Tukey untuk kadar kalsium dan LSD (Least Significance Different) untuk kadar serat kasar sedangkan data 
penilaian kesukaan dianalisis dengan uji Friedman yang dilanjutkan dengan uji Wilcoxon dengan derajat kepercayaan $95 \%$.
HASIL

\section{Kadar Kalsium dan Serat Kasar Kerupuk}

Hasil analisis terhadap kadar kalsium dan serat kasar dapat dilihat pada Lampiran 5 dan secara singkat disajikan pada Tabel 2.

Tabel 2. Hasil Analisis Kadar Kalsium dan Serat Kasar per 100 g Kerupuk

\begin{tabular}{ccc}
\hline \multirow{2}{*}{ Formula } & \multicolumn{2}{c}{ Rerata Kadar Zat Gizi } \\
\cline { 2 - 3 } & Kalsium $(\mathrm{g})$ & Serat Kasar $(\mathrm{g})$ \\
\hline K & $0.05 \pm 0.00^{\mathrm{a}}$ & $1.03 \pm 0.04^{\mathrm{a}}$ \\
F1 & $7.18 \pm 0.04^{\mathrm{b}}$ & $2.11 \pm 0.06^{\mathrm{b}}$ \\
F2 & $6.64 \pm 0.16^{\mathrm{c}}$ & $2.50 \pm 0.08^{\mathrm{c}}$ \\
F3 & $5.15 \pm 0.05^{\mathrm{d}}$ & $2.85 \pm 0.03^{\mathrm{d}}$ \\
F4 & $5.09 \pm 0.10^{\mathrm{d}}$ & $3.09 \pm 0.05^{\mathrm{e}}$ \\
F5 & $4.15 \pm 0.17^{\mathrm{e}}$ & $3.36 \pm 0.23^{\mathrm{f}}$ \\
F6 & $3.79 \pm 0.15^{\mathrm{f}}$ & $4.21 \pm 0.04^{\mathrm{g}}$ \\
\hline & $\mathrm{p}=0.000$ & $\mathrm{p}=0.000$ \\
\hline
\end{tabular}

Keterangan : Angka yang diikuti huruf superscript berbeda menunjukkan beda nyata

Kadar kalsium kerupuk dengan penambahan tepung duri ikan lele dumbo dan bubur rumput laut memiliki rerata antara 3,79$7,18 \mathrm{~g} / 100 \mathrm{~g}$. Penambahan tepung duri ikan lele dumbo dan bubur rumput laut berpengaruh nyata terhadap kadar kalsium kerupuk, kecuali kerupuk F3 tidak berbeda nyata dengan kerupuk F4. Pada umumnya, penambahan tepung duri ikan lele dumbo dan bubur rumput laut meningkatkan kadar kalsium kerupuk dibandingkan dengan kontrol.

Kadar serat kasar kerupuk dengan penambahan tepung duri ikan lele dumbo dan bubur rumput laut memiliki rerata antara 2,11 -
$4,21 \mathrm{~g} / 100 \mathrm{~g}$. Penambahan tepung duri ikan lele dumbo dan bubur rumput laut berpengaruh nyata terhadap kadar serat kasar kerupuk. Pada umumnya, penambahan tepung duri ikan lele dumbo dan bubur rumput laut meningkatkan kadar serat kasar kerupuk dibandingkan dengan kontrol.

\section{Kesukaan Kerupuk}

Kesukaan kerupuk didapatkan melalui uji hedonik yang meliputi warna, aroma, rasa, dan tekstur. Hasil analisis terhadap kesukaan kerupuk dapat dilihat pada Lampiran 6 dan secara singkat disajikan pada Tabel 3.

Tabel 3. Hasil Analisis Kesukaan Kerupuk dengan Penambahan Tepung Duri Ikan Lele Dumbo dan Bubur Rumput Laut

\begin{tabular}{|c|c|c|c|c|c|c|c|c|}
\hline \multirow{2}{*}{$\begin{array}{l}\text { Formul } \\
\mathrm{a}\end{array}$} & \multicolumn{2}{|c|}{ Warna } & \multicolumn{2}{|c|}{ Aroma } & \multicolumn{2}{|c|}{ Rasa } & \multicolumn{2}{|c|}{ Tekstur } \\
\hline & Rerata & Ket & Rerata & Ket & Rerata & Ket & Rerata & Ket \\
\hline $\mathrm{K}$ & $\begin{array}{l}4,60 \pm 0,78 \\
\text { a }\end{array}$ & Suka & $3,97 \pm 1,15^{\mathrm{a}}$ & $\begin{array}{l}\text { Agak } \\
\text { suka }\end{array}$ & $4,30 \pm 1,11^{\mathrm{a}}$ & $\begin{array}{l}\text { Agak } \\
\text { suka }\end{array}$ & $4,61 \pm 0,68^{\mathrm{a}}$ & Suka \\
\hline $\mathrm{F} 1$ & $\underset{\mathrm{e}}{2,58 \pm 1,22}$ & Netra & $3,12 \pm 1,22^{\mathrm{d}}$ & Netral & $3,21 \pm 1,38^{\mathrm{e}}$ & Netral & $2,60 \pm 1,27^{\mathrm{d}}$ & Netra \\
\hline F2 & $\begin{array}{l}3,28 \pm 1,26 \\
d\end{array}$ & $\begin{array}{l}\text { Netra } \\
1\end{array}$ & $3,30 \pm 1,16^{\mathrm{cd}}$ & Netral & $\underset{\mathrm{e}}{3,51 \pm 1,40^{\mathrm{d}}}$ & $\begin{array}{l}\text { Agak } \\
\text { suka }\end{array}$ & $3,29 \pm 1,40^{\mathrm{c}}$ & $\begin{array}{l}\text { Netra } \\
1\end{array}$ \\
\hline F3 & $\begin{array}{l}3,66 \pm 1,19 \\
c\end{array}$ & $\begin{array}{l}\text { Agak } \\
\text { suka }\end{array}$ & $3,49 \pm 1,02^{\mathrm{bc}}$ & Netral & $3,66 \pm 1,25^{\mathrm{d}}$ & $\begin{array}{l}\text { Agak } \\
\text { suka }\end{array}$ & $3,37 \pm 1,36^{\mathrm{c}}$ & $\begin{array}{l}\text { Netra } \\
1\end{array}$ \\
\hline F4 & $\begin{array}{l}3,61 \pm 1,19 \\
c\end{array}$ & $\begin{array}{l}\text { Agak } \\
\text { suka }\end{array}$ & $3,59 \pm 1,06^{\mathrm{b}}$ & $\begin{array}{l}\text { Agak } \\
\text { suka }\end{array}$ & $\underset{\mathrm{b}}{4,11 \pm 1,01^{\mathrm{a}}}$ & $\begin{array}{l}\text { Agak } \\
\text { suka }\end{array}$ & $3,49 \pm 1,39^{c}$ & $\begin{array}{l}\text { Netra } \\
1\end{array}$ \\
\hline F5 & $\begin{array}{l}3,73 \pm 1,33 \\
\mathrm{c}\end{array}$ & $\begin{array}{l}\text { Agak } \\
\text { suka }\end{array}$ & ${ }_{c}^{3,63 \pm 1,34^{\mathrm{ab}}}$ & $\begin{array}{l}\text { Agak } \\
\text { suka }\end{array}$ & $\begin{array}{l}3,73 \pm 1,23^{c} \\
d\end{array}$ & $\begin{array}{l}\text { Agak } \\
\text { suka }\end{array}$ & $3,48 \pm 1,45^{\mathrm{c}}$ & $\begin{array}{l}\text { Netra } \\
1\end{array}$ \\
\hline F6 & $\underset{\mathrm{b}}{4,23 \pm 1,04}$ & $\begin{array}{l}\text { Agak } \\
\text { suka }\end{array}$ & $3,77 \pm 1,05^{\mathrm{ab}}$ & $\begin{array}{l}\text { Agak } \\
\text { suka }\end{array}$ & $\underset{c}{3,99 \pm 1,25^{b}}$ & $\begin{array}{l}\text { Agak } \\
\text { suka }\end{array}$ & $4,22 \pm 1,19^{b}$ & $\begin{array}{l}\text { Agak } \\
\text { suka }\end{array}$ \\
\hline & $\mathrm{p}=0.000$ & & $\mathrm{p}=0.000$ & & $\mathrm{p}=0.000$ & & $\mathrm{p}=0.000$ & \\
\hline
\end{tabular}

Keterangan : Angka yang diikuti huruf superscript berbeda menunjukkan beda nyata 
Nilai rerata warna kerupuk dengan penambahan tepung duri ikan lele dumbo dan bubur rumput laut dapat diterima oleh panelis dengan penilaian suka untuk kerupuk kontrol, penilaian agak suka untuk kerupuk F3, F4, F5, dan F6, sedangkan penilaian netral untuk kerupuk F1 dan kerupuk F2. Hasil uji kesukaan terhadap warna menunjukkan bahwa kerupuk F6 memiliki tingkat kesukaan tertinggi yaitu 4,23 (agak suka) dan kerupuk F1 memiliki tingkat kesukaan terendah yaitu 2,58 (netral). Pada umumnya, penambahan tepung duri ikan lele dumbo dan bubur rumput laut menurunkan kesukaan terhadap warna kerupuk dibandingkan dengan kontrol.

Nilai rerata aroma kerupuk dengan penambahan tepung duri ikan lele dumbo dan bubur rumput laut dapat diterima oleh panelis dengan penilaian suka untuk kerupuk kontrol, penilaian agak suka untuk kerupuk F4, F5, dan F6, dan penilaian netral untuk kerupuk F1, F2 dan F3. Hasil uji kesukaan terhadap aroma menunjukkan bahwa kerupuk F6 memiliki tingkat kesukaan tertinggi yaitu 3,77 (agak suka) dan kerupuk F1 memiliki tingkat kesukaan terendah 3,12 (netral). Pada umumnya, penambahan tepung duri ikan lele dumbo dan bubur rumput laut menurunkan kesukaan terhadap aroma kerupuk dibandingkan dengan kontrol.

Nilai rerata rasa kerupuk dengan penambahan tepung duri ikan lele dumbo dan bubur rumput laut dapat diterima oleh panelis dengan penilaian suka untuk kerupuk kontrol, penilaian agak suka untuk kerupuk F2, F3, F4, F5, dan F6, dan penilaian netral untuk kerupuk F1. Hasil uji kesukaan terhadap rasa menunjukkan bahwa kerupuk F4 memiliki tingkat kesukaan tertinggi yaitu 4,11 (agak suka) sedangkan kerupuk F2 memiliki tingkat kesukaan terendah yaitu 3,21 (netral). Pada umumnya, penambahan tepung duri ikan lele dumbo dan bubur rumput laut menurunkan kesukaan terhadap rasa kerupuk dibandingkan dengan kontrol.

Nilai rerata tekstur kerupuk dengan penambahan tepung duri ikan lele dumbo dan bubur rumput laut dapat diterima oleh panelis dengan penilaian suka untuk kerupuk kontrol, penilaian netral untuk kerupuk F1, F2, F3, F4, dan F5, dan penilaian agak suka untuk kerupuk F6. Hasil uji kesukaan terhadap tekstur menunjukkan bahwa kerupuk F6 memiliki tingkat kesukaan tertinggi yaitu 4,22 (agak suka) sedangkan kerupuk F1 memiliki tingkat kesukaan terendah yaitu 2,60 (netral). Pada umumnya, penambahan tepung duri ikan lele dumbo dan bubur rumput laut menurunkan kesukaan terhadap tekstur kerupuk dibandingkan dengan kontrol.

\section{PEMBAHASAN \\ Kadar Kalsium dan Serat Kasar Kerupuk}

Kadar kalsium pada kerupuk dengan penambahan tepung duri ikan lele dumbo dan bubur rumput laut berkisar antara 3,79-7,18g per $100 \mathrm{~g}$. Kerupuk dengan penambahan tepung duri ikan lele dumbo dan bubur rumput laut memiliki kadar kalsium yang lebih tinggi dibandingkan kerupuk daging ikan dan kerupuk udang. Kadar kalsium kerupuk daging ikan yaitu $0,002 \mathrm{~g} / 100 \mathrm{~g}$ dan kerupuk udang yaitu $0,33 \mathrm{~g} / 100 \mathrm{~g} .{ }^{9}$ Pada penelitian ini, kadar kalsium kerupuk dengan penambahan tepung duri ikan lele dumbo $25 \%$ dan bubur rumput laut $0 \%$ yaitu $7,18 \mathrm{~g} / 100 \mathrm{~g}$ dengan kadar kalsium tepung duri sebesar $9,72 \%$ dan menggunakan tepung tapioka sebanyak $100 \mathrm{~g}$, sedangkan pada penelitian yang dilakukan oleh Rikah, kerupuk dengan substitusi tepung duri ikan patin 30\% memiliki kadar kalsium sebesar $5,4 \mathrm{~g} / 100 \mathrm{~g}$ dengan kadar kalsium duri ikan patin sebesar $26,00 \%$ dan menggunakan tepung tapioka sebanyak 70 g. ${ }^{5}$ Perbedaan kadar kalsium pada kerupuk terjadi karena perbedaan jenis ikan yang digunakan sebagai bahan baku dan jumlah tepung tapioka yang digunakan. Jenis ikan yang berbeda memiliki kandungan mineral yang berbeda pula. ${ }^{5}$

Penambahan tepung duri ikan lele dumbo dan bubur rumput laut berpengaruh nyata terhadap kadar kalsium kerupuk, kecuali kerupuk F3 yang tidak berbeda nyata dengan kerupuk F4 karena kerupuk F3 memiliki kadar kalsium yang mendekati kerupuk F4. Kadar kalsium kerupuk F3 yang mendekati kerupuk F4 tersebut karena memiliki persentase penambahan yang tidak berbeda jauh. Pada kerupuk F3 memiliki penambahan tepung duri ikan lele dumbo sebanyak $15 \%$ dan bubur rumput laut sebanyak 10\% sedangkan kerupuk F4 memiliki penambahan tepung duri ikan lele dumbo sebanyak $10 \%$ dan bubur rumput laut sebanyak $15 \%$.

Kerupuk F1 merupakan kerupuk yang memiliki kadar kalsium tertinggi dibandingkan kerupuk variasi lainnya. Kadar kalsium yang tinggi tersebut disebabkan oleh kadar kalsium tepung duri ikan lele dumbo yang lebih tinggi daripada kadar kalsium tepung tapioka dan rumput laut. Kadar kalsium pada tepung tapioka sebesar $0,084 \mathrm{mg} / 100 \mathrm{~g}^{5}$, pada bubur rumput laut sebesar $75,65 \mathrm{mg} / 100 \mathrm{~g}$ dan pada tepung duri ikan lele 
dumbo sebesar $9.718 \mathrm{mg} / 100 \mathrm{~g}$. Tepung duri ikan lele dumbo yang memiliki kadar kalsium lebih tinggi tersebut menyebabkan kerupuk F1 memiliki kadar kalsium tertinggi. Namun, kadar kalsium yang tinggi tersebut mempengaruhi tekstur kerupuk menjadi lebih berpasir. ${ }^{5}$ Kalsium dalam tepung duri berbentuk garam yang sukar larut air, yakni dikalsium fosfat dan trikalsium fosfat. ${ }^{16}$

Kerupuk F6 memiliki kadar kalsium yang lebih rendah dibandingkan dengan kerupuk variasi lainnya. Hal ini karena pada kerupuk F6 hanya terdapat penambahan bubur rumput laut yang memiliki kadar kalsium lebih rendah dibandingkan tepung duri ikan lele dumbo. Namun, bubur rumput laut memiliki kadar kalsium lebih tinggi dibandingkan tepung tapioka sehingga kadar kalsium kerupuk F6 lebih tinggi dibandingkan kerupuk kontrol.

Kadar serat kasar pada kerupuk dengan penambahan tepung duri ikan lele dumbo dan bubur rumput laut berkisar antara 2,11 $4,21 \mathrm{~g} / 100 \mathrm{~g}$. Variasi penambahan tepung duri ikan lele dumbo bubur rumput laut meningkatkan kadar serat kasar dibandingkan kerupuk kontrol. Kerupuk F6 merupakan kerupuk dengan kadar serat kasar tertinggi dibandingkan kerupuk variasi lainnya. Hal tersebut disebabkan oleh bubur rumput laut memiliki kadar serat kasar yang lebih tinggi dibandingkan tepung tapioka dan tepung duri ikan lele dumbo. Kadar serat kasar pada tepung tapioka sebesar $0,41 \mathrm{~g} / 100 \mathrm{~g}^{5}$, pada tepung duri sebesar $1,74 \mathrm{~g} / 100 \mathrm{~g}$ dan pada bubur rumput laut sebesar $5,14 \mathrm{~g} / 100 \mathrm{~g}$. Bubur rumput laut yang memiliki kadar serat kasar yang lebih tinggi tersebut menyebabkan peningkatan kadar serat kasar pada kerupuk. Serat kasar adalah serat dalam suatu bahan pangan yang masih tahan setelah direaksikan dengan asam kuat dan basa kuat sehingga terjadi kehilangan selulosa sekitar 50\% dan hemiselulosa sekitar $85 \%{ }^{22}$ Selulosa yang masih terdapat pada serat kasar tersebut memiliki kemampuan untuk menyerap air. ${ }^{2}$ Adanya selulosa tersebut dapat menurunkan pengembangan kerupuk apabila dilakukan penambahan secara berlebihan. Namun, pada penelitian ini kerupuk dengan penambahan bubur rumput laut tertinggi masih memiliki pengembangan yang baik.

Kerupuk F1 memiliki kadar serat kasar yang lebih rendah dibandingkan dengan kerupuk variasi lainnya. Hal ini karena pada kerupuk F1 hanya terdapat penambahan tepung duri ikan lele dumbo yang memiliki kadar serat kasar lebih rendah bila dibandingkan bubur rumput laut. Namun, kadar serat kasar tepung duri ikan lele dumbo lebih tinggi dibandingkan tepung tapioka. Hal ini menyebabkan kadar serat kasar kerupuk F1 lebih tinggi dibandingkan kerupuk kontrol.

\section{Kesukaan Kerupuk}

Warna kerupuk yang dihasilkan pada beberapa variasi penambahan tepung duri ikan lele dumbo dan bubur rumput laut memiliki tingkat penilaian agak suka, yakni antara 3,61 - 4,23, kecuali kerupuk kontrol yang mendapat penilaian suka, kerupuk F1 dan F2 yang mendapat penilaian netral. Penambahan tepung duri ikan lele dumbo dan bubur rumput laut menurunkan kesukaan terhadap warna kerupuk dibandingkan dengan kerupuk kontrol. Hal ini karena panelis menyukai kerupuk dengan warna yang cerah.

Formulasi kerupuk dengan penambahan tepung duri ikan lele dumbo dan bubur rumput laut menghasilkan warna kuning kecoklatan. Warna kuning kecoklatan tersebut disebabkan oleh tepung duri ikan lele dumbo yang berwarna cokelat dan bubur rumput laut yang berwarna kuningkecoklatan.

Kerupuk F1 memiliki warna yang lebih gelap dibandingkan kerupuk lainnya. Hal tersebut disebabkan oleh kerupuk F1 yang kurang mengembang sehingga warna yang dihasilkan menjadi lebih gelap dibandingkan kerupuk lain. ${ }^{5}$ Berbeda dengan kerupuk F1, kerupuk F6 yang memiliki warna yang cenderung mendekati kontrol karena kerupuk F6 mengembang dengan baik.

Selain itu, warna kuning kecoklatan pada kerupuk disebabkan oleh adanya reaksi browning non enzimatis (maillard). Reaksi maillard terjadi karena adanya asam amino lisin dan glukosa yang bereaksi pada suhu tinggi sehingga menghasilkan melanoidin yang berwarna cokelat. ${ }^{23}$ Asam amino lisin tersebut berasal dari pemecahan struktur heliks dan ikatan peptida kolagen akibat pemanasan secara bertahap. ${ }^{24}$ Kolagen merupakan sebagian besar bentuk protein pada tepung duri. Selain itu, pada tepung duri pun terdapat glukosa meskipun dalam jumlah yang terbatas. ${ }^{25}$ Pada bubur rumput laut juga terdapat asam amino lisin meskipun dalam jumlah yang terbatas ${ }^{26}$ dan glukosa $^{27}$.

Penilaian panelis terhadap aroma kerupuk dengan penambahan tepung duri ikan lele dumbo dan bubur rumput laut dinilai dengan tingkat penilaian agak suka dengan rerata nilai antara 3,59 - 3,77, begitu pula dengan kontrol, sedangkan kerupuk F1, F2 dan F3 mendapat penilaian netral. Penambahan tepung duri ikan lele dumbo dan bubur rumput laut menurunkan kesukaan terhadap aroma kerupuk dibandingkan dengan kerupuk 
kontrol. Hal ini karena panelis menyukai kerupuk dengan aroma yang tidak terlalu amis.

Aroma amis pada kerupuk tersebut berkenaan dengan bahan baku yang digunakan yakni tepung duri ikan lele dumbo dan bubur rumput laut. Aroma amis tepung duri berasal dari ikan lele dumbo yang pada dasarnya telah memiliki aroma amis. Aroma amis ikan berasal dari komponen nitrogen yaitu guanidin, trimetil amin oksida (TMAO), dan turunan imidazol. ${ }^{28}$ Selain itu, proses pemanasan dalam pengolahan dapat menyebabkan reaksi maillard yang menghasilkan senyawa-senyawa volatil yang mudah menguap sehingga meningkatkan aroma ${ }^{29}$ amis pada tepung duri dan bubur rumput laut. Reaksi maillard tersebut terjadi karena adanya asam amino-asam amino yang berasal dari protein yang terdenaturasi selama proses pengolahan. ${ }^{29}$ Kandungan protein pada tepung duri lebih banyak dibandingkan kandungan protein pada rumput laut sehingga aroma amis pada tepung duri ikan lele dumbo lebih kuat daripada bubur rumput laut. Kandungan protein pada tepung duri yaitu $58,57 \%$, sedangkan pada bubur rumput laut yaitu $3,89 \%$. Oleh karena itu, kerupuk F1 cenderung beraroma lebih amis dibandingkan kerupuk lainnya. Berbeda dengan kerupuk lainnya, kerupuk kontrol cenderung beraroma bawang putih.

Rasa kerupuk dengan penambahan tepung duri ikan lele dumbo dan bubur rumput laut memiliki tingkat penilaian agak suka dengan rerata nilai antara 3,51 - 4,11, begitupun dengan kontrol yang mendapat penilaian agak suka, sedangkan kerupuk F1 mendapat penilaian netral. Penambahan tepung duri ikan lele dumbo dan bubur rumput laut menurunkan kesukaan terhadap rasa kerupuk dibandingkan dengan kerupuk kontrol. Hal ini karena panelis menyukai kerupuk dengan rasa yang gurih.

Kerupuk yang terdapat penambahan tepung duri ikan lele dumbo memiliki rasa khas ikan. Hal ini berkaitan dengan karakter tepung duri ikan lele dumbo sebagai bahan baku. Kerupuk F1 memiliki rasa khas ikan yang lebih kuat dibandingkan kerupuk lainnya sehingga kerupuk F1 mendapat penilaian netral. Berbeda dengan kerupuk variasi lainnya, kerupuk F6 yang mendapat penilaian agak suka. Hal ini disebabkan oleh adanya asam amino glutamat pada rumput laut $^{26}$ yang menimbulkan rasa umami $^{30}$ sehingga kerupuk F6 cenderung disukai.

Penilaian terhadap tekstur merupakan penilaian utama pada produk kerupuk. Tekstur kerupuk yang diharapkan adalah kerupuk dengan tekstur renyah. Pada kerupuk dengan penambahan tepung duri ikan lele dumbo dan bubur rumput laut memiliki penilaian kesukaan netral antara 2,60 3,48 , kecuali kerupuk F6, yang mendapat penilaian agak suka serta kerupuk kontrol yang mendapat penilaian suka. Penambahan tepung duri ikan lele dumbo dan bubur rumput laut menurunkan kesukaan terhadap tekstur kerupuk dibandingkan dengan kerupuk kontrol. Hal ini karena panelis menyukai kerupuk dengan tekstur yang renyah.

Penilaian terhadap tekstur dipengaruhi oleh pengembangan kerupuk. Pengembangan kerupuk dipengaruhi oleh kandungan yang terdapat dalam bahan baku. Bahan baku yang mengandung protein tinggi membuat pengeluaran air pada kerupuk menjadi sulit karena rongga udara yang terbentuk pada saat penggorengan semakin kecil. Pembentukan rongga udara yang semakin kecil membuat kerupuk kurang mengembang. Hal tersebut disebabkan oleh gugus hidrofil pada protein lebih banyak dibandingkan pati. Pengembangan kerupuk yang kurang sempurna menyebabkan tekstur kerupuk menjadi keras. ${ }^{5}$

Kerupuk F1 memiliki penilaian kesukaan terendah karena memiliki tekstur yang keras. Hal tersebut disebabkan oleh tepung duri ikan lele dumbo yang memiliki kadar protein cukup tinggi yaitu 58,57\%. Kerupuk F6 cenderung disukai karena kerupuk tersebut memiliki tekstur yang renyah. Hal tersebut disebabkan oleh bubur rumput laut yang memiliki kadar protein rendah yaitu $3,89 \%$.

Pada rumput laut terdapat serat kasar yang cukup tinggi. Pada serat kasar masih terdapat selulosa $^{22}$ yang mampu menyerap air ${ }^{2}$. Adanya selulosa yang tinggi tersebut dapat menurunkan pengembangan kerupuk apabila dilakukan penambahan secara berlebihan. Namun, pada penelitian ini kerupuk dengan penambahan bubur rumput laut tertinggi, yakni kerupuk dengan penambahan tepung duri $0 \%$ dan bubur rumput laut $25 \%$, masih memiliki pengembangan yang baik.

Kerupuk F1 memiliki tekstur berpasir. ${ }^{5}$ Kerupuk memiliki tekstur berpasir karena adanya kadar abu yang cukup tinggi yaitu 19,51\% dan protein pada tepung duri ikan lele dumbo yang sebagian besar dalam bentuk kolagen. Kolagen dan abu bukan merupakan komponen yang mudah larut air ${ }^{16}$ sehingga memberikan tekstur berpasir setelah digoreng.

\section{Rekomendasi Kerupuk}

Kerupuk yang direkomendasikan adalah kerupuk F4, yaitu kerupuk dengan penambahan 
tepung duri ikan lele dumbo $10 \%$ dan bubur rumput laut $15 \%$, yang memiliki kadar kalsium sebesar $0,05 \mathrm{~g} / \mathrm{keping}$ dan kadar serat kasar sebesar $0,03 \mathrm{~g} / \mathrm{keping}$, memiliki rasa yang paling disukai diantara kerupuk variasi penambahan lainnya, serta memiliki warna, aroma, dan tekstur yang masih dapat diterima oleh panelis. Kadar kalsium dan serat kasar yang cukup tinggi pada kerupuk tersebut diharapkan dapat menjadi snack kaya kalsium dan serat.

Konsumsi kalsium dan serat sangat dibutuhkan oleh tubuh, tetapi hendaknya tidak berlebihan. Asupan serat yang berlebihan akan menghambat penyerapan garam mineral sehingga bisa kekurangan mineral. Selain itu, sifat serat yang viskos dapat menyumbat usus halus yang kemudian dapat menyebabkan terjadinya penyakit ileus. ${ }^{31}$ Asupan kalsium yang berlebih akan menyebabkan penyakit batu ginjal. ${ }^{2}$

\section{KESIMPULAN DAN SARAN \\ Kesimpulan}

1. Penambahan tepung duri ikan lele dumbo dan bubur rumput laut meningkatkan kadar kalsium dan serat kasar kerupuk dibandingkan dengan kontrol.

2. Penambahan tepung duri ikan lele dumbo $25 \%$ dan bubur rumput laut $0 \%$ meningkatkan kadar kalsium dan serat kasar kerupuk dibandingkan dengan kontrol.

3. Penambahan tepung duri ikan lele dumbo $20 \%$ dan bubur rumput laut 5\% meningkatkan kadar kalsium dan serat kasar kerupuk dibandingkan dengan kontrol.

4. Penambahan tepung duri ikan lele dumbo $15 \%$ dan bubur rumput laut $10 \%$ meningkatkan kadar kalsium dan serat kasar kerupuk dibandingkan dengan kontrol.

5. Penambahan tepung duri ikan lele dumbo $10 \%$ dan bubur rumput laut $15 \%$ meningkatkan kadar kalsium dan serat kasar kerupuk dibandingkan dengan kontrol.

6. Penambahan tepung duri ikan lele dumbo 5\% dan bubur rumput laut $20 \%$ meningkatkan kadar kalsium dan serat kasar kerupuk dibandingkan dengan kontrol.

7. Penambahan tepung duri ikan lele dumbo $0 \%$ dan bubur rumput laut $25 \%$ meningkatkan kadar kalsium dan serat kasar kerupuk dibandingkan dengan kontrol.

8. Penambahan tepung duri ikan lele dumbo dan bubur rumput laut pada kerupuk menurunkan kesukaan meliputi warna, aroma, rasa, dan tekstur kerupuk dibandingkan dengan kontrol, tetapi masih dapat diterima oleh panelis.

9. Penambahan tepung duri ikan lele dumbo $25 \%$ dan bubur rumput laut $0 \%$ pada kerupuk menurunkan kesukaan meliputi warna, aroma, rasa, dan tekstur kerupuk dibandingkan dengan kontrol, tetapi masih dapat diterima oleh panelis.

10. Penambahan tepung duri ikan lele dumbo $20 \%$ dan bubur rumput laut 5\% pada kerupuk menurunkan kesukaan meliputi warna, aroma, rasa, dan tekstur kerupuk dibandingkan dengan kontrol, tetapi masih dapat diterima oleh panelis.

11. Penambahan tepung duri ikan lele dumbo $15 \%$ dan bubur rumput laut 10\% pada kerupuk menurunkan kesukaan meliputi warna, aroma, rasa, dan tekstur kerupuk dibandingkan dengan kontrol, tetapi masih dapat diterima oleh panelis.

12. Penambahan tepung duri ikan lele dumbo $10 \%$ dan bubur rumput laut $15 \%$ pada kerupuk menurunkan kesukaan meliputi warna, aroma, rasa, dan tekstur kerupuk dibandingkan dengan kontrol, tetapi masih dapat diterima oleh panelis.

13. Penambahan tepung duri ikan lele dumbo $5 \%$ dan bubur rumput laut 20\% pada kerupuk menurunkan kesukaan meliputi warna, aroma, rasa, dan tekstur kerupuk dibandingkan dengan kontrol, tetapi masih dapat diterima oleh panelis.

14. Penambahan tepung duri ikan lele dumbo $0 \%$ dan bubur rumput laut $25 \%$ pada kerupuk menurunkan kesukaan meliputi warna, aroma, rasa, dan tekstur kerupuk dibandingkan dengan kontrol, tetapi masih dapat diterima oleh panelis.

\section{Saran}

1. Kerupuk yang direkomendasikan adalah kerupuk F4, yaitu kerupuk dengan penambahan tepung duri $10 \%$ dan bubur rumput laut $15 \%$ karena memiliki kadar kalsium dan serat kasar yang cukup tinggi, memiliki rasa yang paling disukai diantara kerupuk variasi lainnya, dan memiliki warna, aroma, dan tekstur yang masih dapat diterima oleh panelis.

2. Perlu dilakukan penanganan khusus untuk peningkatan kualitas sensori kesukaan kerupuk seperti menambahkan cuka pada saat duri direbus, menambahkan pewarna makanan pada 
kerupuk, dan menambahkan bumbu perisa sehingga kerupuk dapat lebih diterima panelis.

\section{DAFTAR PUSTAKA}

1. Depkes RI. Pedoman Pengendalian Osteoporosis. Jakarta: Departemen, 2008.

2. Sunita Almatsier. Prinsip Dasar Ilmu Gizi. Jakarta: PT Gramedia Pustaka Utama. 2002. p. 43, 236-238.

3. M. Bahrun. Fungsionalisasi Cangkang Kerang Hijau (Perna viridis) sebagai Peningkat Kadar Kalsium Susu Fermentasi. Bogor: Institut Pertanian Bogor. 2010. p. 4

4. Om Rois. Ikan Teri dan Manfaat Supernya, Pemantauan Pasar Komoditas Bahan Pokok, Kementerian Perdagangan Republik Indonesia. 2012. Available URL at: http://ews.kemendag.go.id/berita/NewsDetail.aspx?v berita=3204 [diakses: 24 Oktober 2012]

5. Rikah Tababaka. Pemanfaatan Tepung Tulang Ikan Patin (Pangasius sp) sebagai Bahan Tambahan Kerupuk [Skripsi]. Institut Pertanian Bogor. 2004

6. Effatha Tambunan. Boyolali Jadi Sentra Lele Terpadu. 2011. Available URL at: http://www.kkp.go.id/index.php/arsip/c/5956/Boyola li-Jadi-Sentra-Lele-Terpadu/. [diakses: 15 Agustus 2011]

7. K. Mahyuddin. Panduan Lengkap Agribisnis Lele. Jakarta: Penebar Swadaya. 2007. p. 3,6,7,15,20.

8. Eni Widyastuti, editor. Bikin Kerupuk Tulang Ikan, Siswa Muhammadiyah 1 Solo Raih Medali Perunggu. 2011. Available URL at: http://www.solopos.com/2011/10/18/bikin-kerupuktulang-ikan-siswa-sma-muhammadiyah-1-solo-raihmedali-perunggu-120175. [diakses: 18 Oktober 2011]

9. Direktorat Kredit BPR dan UMKM. Pola Pembiayaan Usaha Kecil (PPUK) Pengolahan Kerupuk Ikan. Bank Indonesia. 2007. p.3, 9.

10. Departemen Gizi dan Kesehatan Masyarakat Fakultas Kesehatan Masyarakat Universitas Indonesia. Gizi dan Kesehatan Masyarakat. Jakarta: PT Grafindo Persada, 2007.p.34 - 37.

11. Restiana A. Wisnu., dan Diana Rachmawati. Analisa Komposisi Nutrisi Rumput Laut (Eucheuma cottonii) di Pulau Karimun Jawa dengan Proses Pengeringan Berbeda. 2009. Semarang: Universitas Diponegoro.p.1

12. Rosmawaty P. Pengolahan Rumput Laut Skala Rumah Tangga. Badan Penelitian dan Pengembangan Kelautan dan Perikanan Kementrian Kelautan dan Perikanan. Kendari: 2011 [diakses: 12 Mei 2012]

13. Jana T. Anggadiredja, Achmad Zatnika., Heri Purwoto., Sri Istini. Seri Agribisnis Rumput Laut. Jakarta: Penebar Swadaya. 2006. p.86-87.

14. Gracia-Casal,MN,Ana CP,Irene L,Jose R,Maria FQ.High iron content and bioavailability in humans from four species of marine algae.The Journal of Nutrition.2007 J.Nutr.137:2691-2695.
15. Rudi Wahyono., dan Marzuki. Seri Agritekno: Pembuatan Aneka Kerupuk. Jakarta: Penebar Swadaya; 2007.p.1.

16. Mulia Nurhasan. Kajian Potensi Limbah Tulang Ikan Patin (Pangasius sp) sebagai Alternatif Sumber Kalsium dalam Produk Mie Kering [Skripsi]. Institut Pertanian Bogor; 2004.

17. Ubaedillah. Kajian Rumput Laut Eucheuma cottonii sebagai Sumber Serat Alternatif Minuman Cendol Instan [Thesis]. Institut Pertanian Bogor; 2008.

18. Diah Purwaningrum. Pengaruh Rasio Penambahan Rumput Laut Eucheuma cottonii yang Berbeda terhadap Tingkat Kemekaran Kerupuk Rumput Laut [Skripsi]. Universitas Diponegoro. 2008.

19. Abdul Rohman, Sumantri. Analisis Makanan. Jogjakarta: Gajah Mada University. 2007. p. 217219.

20. Andarwulan N, Kusnandar F, Herawati D. Analisis Pangan. Jakarta: Dian Rakyat; 2011. p. 42.

21. Dwi Setyaningsih., Anton Apriyantono., Maya Puspita Sari. Analisis Sensori untuk Industri Pangan dan Agro. Bogor: IPB Press. 2010. p.18,18,21,43-9, 63-7.

22. Tensiska. Serat Makanan. Bandung: Universitas Padjajaran. 2006. P.7.

23. F. G. Winarno. Kimia Pangan dan Gizi. Jakarta: PT Gramedia Pustaka Utama. 1992. p. 41, 59.

24. Abubakar Sidik Katili. Struktur dan Fungsi Kolagen. Jurnal Pelangi Ilmu Vol.2 No.5. 2009. p.21-23.

25. Ida Musfiroh, Wiwiek Indriyati, Emma Surahman, Sri Adi Sumiwi, Muchtaridi, Mutakin, Jutti Levita. Analisis dan Aktivitas Antiinflamasi Tulang Rawan Ikan Hiu. Universitas Padjajaran; Farmaka, Volume 7 Nomor 2. Agustus 2009

26. Matanjun, Patricia., Mohamed, Suhaila., Mustapha, Noordin., Muhammad, Kharidah. Nutrient content of tropical edible seaweeds, Eucheuma cottonii, Caulerpa lentillifera and Sargassum polycystum. J Appl Phycol (2009) 21:75-80.

27. Jose M Estevez, Marina Ciancia, Alberto S. Cerezo. The System of Low-Molecular-Weight Carrageenans and Agaroids from The RoomTemperature-Extracted Faction of Kappaphycus alvarezii. Carbohydrate Research. 325 (2000) 287299

28. Suseno, S. Pipit, S. Darma, SW. Pengaruh Penambahan Daging Lumat Ikan Nilem (Ostheochilus hasselti) pada Pembuatan Simping sebagai Makanan Camilan. Bulletin Teknologi Hasil Perikanan Vol VII No 1 Tahun 2004. Jakarta.

29. R. A. Lawrie. Ilmu Daging. Jakarta: UI Press; 2001. p. 294.

30. Shizuko Yamaguchi dan Kumiko Ninomiya. Umami dan Kelezatan Makanan. Journal of Nutrition 2000; 130: 921S-926S.

31. Tirtawanata, T.C. 2006. Makanan dalam Perspektif Al-Qur'an dan Ilmu Gizi. Jakarta: Balai Penerbit FKUI. 